\title{
KONSTANTEGO MARII GÓRSKIEGO LEKTURA OŚWIECENIA
}

Słowa kluczowe: K.M. Górski, Oświecenie, Młoda Polska, poezja, historia Keywords: K.M. Górski, Enlightenment, Young Poland movement, poetry, history

Chciałbym rozważyć w tym studium następujący problem badawczy: jak Konstanty Maria Górski (1862-1909) w swojej pracy intelektualnej i literackiej obserwował różne wymiary Oświecenia. W czytaniu i dekodowaniu Oświecenia interesowały go: genologia, biografie i epistolografie pisarzy wieku rozumu i świateł, myśl społeczno-polityczna oraz specyfika edukacji. Wnikliwa i prowadzona przez wiele lat lektura Oświecenia pozwoliła Górskiemu dostrzec wagę kwestii patriotyzmu w tamtej epoce. Oświecenie było przedmiotem jego refleksji badawczej, ale szczególną wizję kultury tej epoki przedstawił w utworze literackim pt. Biblioman. Interesującym kontekstem badań Górskiego nad Oświeceniem, a poniekąd i wymowy wspomnianej noweli, wydaje się krytyka literacka Ostapa Ortwina dotycząca poezji Oświecenia. Omawiam ją w ostatniej części artykułu.

\section{Badania Górskiego nad Oświeceniem}

Biografią metrykalną wpisuje się autor Bibliomana w pokolenie młodopolan. Jednak biografia umysłowa poety, nowelisty, literaturoznawcy epoki Oświecenia, filologa oraz krytyka literackiego i teatralnego, kierownika Biblioteki Polskiej w Paryżu w latach 1896-1899, wykładowcy dziejów malarstwa, docenta Szkoły Sztuk Pięknych w Krakowie, przekonuje, że był to twórca osobny ${ }^{1}$.

\footnotetext{
${ }^{1}$ Warto jedynie dodać, że we wczesnym okresie twórczym zafascynowany był, jak większość modernistów, kulturą i tradycją starożytnych, czy parnasizmem francuskim. Zainteresowanie epokami dawnymi i starożytnością przyczyniło się również do licznych tłumaczeń, m.in. transkrypcji z Horacego, aprobatywnie przyjętych przez Lucjana Rydla czy Tadeusza Sinkę. Próby literackie w poezji zaowocowały u Górskiego tekstami poetyckimi o starannej formie filozoficzno-refleksyjnej. Ażurowość formy,
} 
Najważniejszy wątek zainteresowań badawczych wyznaczają u Górskiego nieustanne powroty do światopoglądu i literatury Oświecenia, w tym próby rozpoznania istoty prawideł gatunkowych oraz biografii jej najbardziej znanych twórców².

Droga myśli historyka literatury wiedzie od problemów estetycznych, genologicznych, filozoficznych i biograficznych kształtujących różnorodność i specyfikę polskiego Oświecenia aż do kwestii patriotycznych i politycznych. Górski w 1887 roku na łamach „Przeglądu Polskiego” opublikował obszerne Studia nad bajkami Krasickiego (vol. 85, 185-215, 494-510; vol. 86, 35-61). Zwraca tu uwagę, że zarówno Bajki i przypowieści, jak i Bajki nowe, zachowały świeżość, „urok i siłę" ${ }^{3}$. W podkreślaniu aktualności bajek dwa argumenty okazują się dla Górskiego ważne. Po pierwsze stała obecność bajek na przestrzeni dziejów uświadamia mu, że są one żywe i nośne; po drugie bajki tworzone przez Krasickiego odbijają jednocześnie ponadczasową rzeczywistość i bieżącą chwilę.

Zdaniem Górskiego, noszą one również ślady wpływu francuskiego. I choć Krasicki nierzadko czerpał ,przedmiot z gadatliwych francuskich pisarzy XVIII w., nieudolnych i [z]manierowanych naśladowców La Fontaine'a"4, to specyfika natury i intelektu zbliżyła go do oryginalnego wzoru La Fontaine'a oraz do światopoglądu i estetyki ufundowanych na metodzie Boileau. Górski stwierdza też, że Krasickiemu blisko było do literatury rozumnej, jasnej, do klarownego wywodu, którym charakteryzował się dyskurs filozoficzny Kartezjusza. Dominantą refleksji Krasickiego stało się bowiem przekonanie o prymacie natury człowieka nad przyrodą.

misterność wykonania, powściągliwość poetycka oraz dystans do ukazywanej rzeczywistości bliskie były pomysłom parnasistowskim. W cyklu $Z$ teki podróżnej, w Liściach wiosennych. Poezjach (1879) czy Wierszem. 1883-1893 (1904) znajduje się wiele wierszy sceptyczno-pesymistycznych, wyrażających zwątpienie w możliwość poznania prawideł świata czy ironię wobec ludzi, zdarzeń i zjawisk, nad którymi trudno zapanować.

${ }^{2}$ Inaczej lektura Oświecenia ujawnia swoje znaczenie u Stefana Żeromskiego, Wacława Berenta, Tadeusza Micińskiego, Władysława Stanisława Reymonta czy Kazimierza Przerwy-Tetmajera. O specyfice nawiązań do tradycji Oświecenia i obecności narracji oświeceniowej w dyskursie literackim i publicystycznym pisarzy pokolenia młodopolskiego vide Dawid Maria Osiński, „Żeromski wobec tradycji Oświecenia", in Żeromski i inni, ed. Maria Jolanta Olszewska et Monika Gabryś-Sławińska (Lublin: UMCS, 2016), 59-100; idem, „Młoda Polska i/a Oświecenie”, in Młoda Polska w najnowszych badaniach, ed. Edward Jakiel, Tadeusz Linkner (Gdańsk: UG, 2016), 87-117; idem, „Figury oświeconych i figury Oświecenia w dramacie historycznym drugiej połowy XIX wieku", in W teatrze dziejów. Dramat historyczny ostatnich 150 lat: problemy lektury, ed. Maria Jolanta Olszewska et Dawid Maria Osiński (Warszawa: Wydział Polonistyki UW, 2016), 335-355; idem, „Reymonta spotkania z Oświeceniem”, in „Wskrzesić choćby chwilę. Władystawa Reymonta zmagania z myśla i forma, ed. Radosław Okulicz-Kozaryn, Mateusz Bourkane (Poznań, 2017).

${ }^{3}$ Konstanty M. Górski, „Studia nad bajkami Krasickiego”, Przeglad Polski, no. 254 (1887), vol. 85 (1, 22): 186.

${ }^{4}$ Ibidem, 188. 
Kiedy osiemnastowieczni pisarze wykładają w tragedii nowe zasady filozoficzne, wtłaczając je w coraz słabsze aleksandryny ${ }^{5}$, Krasicki - zdaniem Górskiego - skłania się ku chrześcijańskiemu stanowisku poetów XVII wieku. Opóźnienie wobec Francji badacz „księcia poetów” uznaje za charakterystyczną cechę polskiego XVIII stulecia, „młodszości” naszego cywilizacyjnego rozwoju ${ }^{6}$. Historyk i badacz literatury Oświecenia podkreśla, że Krasicki widział wzory artystyczne i moralne w twórczości La Fontaine'a, Moliera i pani Sévigné, którzy byli bliżsi Polakom pod względem upodobań i uczuciowości

Górski drobiazgowo i wnikliwie wykazywał tu podobieństwa bajek Krasickiego do bajek nie tylko Jeana de La Fontaine'a, lecz także François Lamotte'a, Jeana-Jacques'a Boisarda, Gottlieba Konrada Pfeffela, Joachima Camerariusa, Laurentiusa Abstemiusa, a w konsekwencji tych zestawień analitycznych potwierdzał osobność i oryginalność rozstrzygnięć Krasickiego na tle współczesnej mu rodzimej praktyki literackiej. Bajki nowe są, zdaniem Górskiego, przykładem ideału zwięzłości. W związku z tym Górski konstruuje ważną definicję określającą specyfikę gnomicznej natury tej formy miniatury literackiej. A dzięki temu dowodzi odpowiedniości bajki do duchowej natury Polaków i adekwatności gatunku bajki jako formy lirycznego wyznania. Dlatego rysuje specyficzny obraz sytuacji, właściwej Polakom XVIII wieku, charakterystyczny dla polskich realiów i polskiej mentalności:

Polska proza nie nadaje się do pogadanki, do salonowej komedii, do powieści nawet, jeżeli nie jest historyczną lub ludową, wtedy bowiem już bywa poetyczną prozą. I nic w tym dziwnego: naród, który na dworze nie mówił prawie własnym językiem, w dyplomacji go nie wyłamał, a w życiu towarzyskim nie zawsze go do dziś dnia używa, mógł na mownicy i w pieśni dać swojej mowie szlachetność, podniosłość i siłę, ale go do wszystkich swoich potrzeb nie nagiął i wykwintności mu nie dał. Myśli bywały nieraz wytworniejsze niż słowa; uciekano się wtedy do gotowej francuszczyzny ${ }^{8}$.

Górski dowodzi, że poza Ptaszkami w klatce nie widać w apologach Krasickiego odniesień do polskich stosunków politycznych w XVIII wieku, w przeciwieństwie do bajek Niemcewicza, Morawskiego, Siemieńskiego, które „miewały

${ }^{5}$ I choć Górski w dalszych partiach wywodu stwierdzi, że sam Krasicki wykazuje predylekcję do aleksandrynu, to doda od razu, że ma również naturalną dla XVIII wieku skłonność do uszczypliwych poemacików. Konstanty M. Górski, „Studia nad bajkami Krasickiego”, Przegląd Polski, no. 255 (1887), vol. 85 (3, 22): 495.

${ }^{6}$ Konstanty M. Górski, „Studia nad bajkami Krasickiego”, Przegląd Polski, no. 254 (1887), vol. 85 (1, 22): 192.

${ }^{7}$ Górski wchodzi tu również w dialog z rozpoznaniami Piotra Chmielowskiego (zamieszczonymi na łamach „Niwy” (vol. XVI, 506-507), dotyczącymi specyfiki pisarskiej Krasickiego: „Miał on dowcip Voltaire'a, jak mówi p. Chmielowski wystarczający na uchwycenie śmieszności, nie dość wielki, aby człowieka lub sytuacje stworzyć". Ibidem, 200.

${ }^{8}$ Konstanty M. Górski, „Studia nad bajkami Krasickiego”, Przegląd Polski, no. 255 (1887), vol. $85(3,22)$ : 509-510. 
nieraz polityczne aluzje i dowiodły, jaką wyborną bronią bywa bajka" ${ }^{\text {. }}$. Dyspozycje artystyczne i światopogląd księcia poetów, ukształtowany na tle kierunków filozoficznych XVIII wieku, najciekawiej obecne są, zdaniem Górskiego, w bajkach poświęconych filozofom. Wynika to z tego, że Krasicki był zawsze obrońcą praktycznego rozsądku. Górski na koniec obszernego studium o bajkach Krasickiego określa wybór formy artystycznej księcia poetów jako świadomą, zdystansowaną, intelektualną (ale i empatyczną) diagnozę problemów codziennego życia:

\begin{abstract}
W walkach, które XVIII wiek prowadził, stanął do szeregu taki Krasicki. Zasługę jego i jemu podobnych uznać i dziś wzór taki naśladować wypada. W wyjątkowych położeniach i chwilach, mianuje się poetów dyktatorami narodów i wieszczami nazywa. Zawsze tak żyć nie można. Poza tą poezją zapału, jest zresztą i druga miary, powagi, doskonałej sztuki, poezja ogólniejsza, spokojna... A i ta ma współczucie dla słabych i biednych, i ona umie odczuć ten wielki prąd, co nas, jak rzeki do morza, ku wieczności niesie ${ }^{10}$.
\end{abstract}

W kontekście dotychczasowych ustaleń na temat bajek Krasickiego warto dodać, że Górski doskonalił twórczy namysł nad gatunkiem bajki. W 1888 roku zrobił doktorat w Berlinie na podstawie dysertacji Die Fabel vom Löwenantheil in ihrer geschichtlichen Entwicklung (rozprawę Stanisław Pigoń przetłumaczył jako Bajkę o lwim dziale w rozwoju historycznym i umieścił w Pismach literackich Górskiego ${ }^{11}$ ). Na wstępie wyjaśnione tu zostało znaczenie formuły „o lwim dziale”, mającej charakter skrzydlatego słowa. Górski próbuje określić przy każdej realizacji tej formuły znaczenie morału (zależne od języka i od kręgu kulturowego). Przytacza drobiazgowo przykłady potwierdzające używanie tej formuły przez różnorodne tradycje bajki w całej Europie na przestrzeni dziejów, począwszy od starożytności ${ }^{12}$.

W duchu wczesnodwudziestowiecznej komparatystyki Górski próbował pokazać również specyfikę bajek Krasickiego na tle przemian bajki europejskiej oraz realizacji gatunkowych i genologicznych bajek niemieckich czy francuskich. Określał dystynktywne cechy bajek Krasickiego, klasyfikował ich motywy i wątki. Zastosowana przez Górskiego metoda oraz sposób dowodzenia lokują się w szkole Hyppolite'a Taine'a - notabene autora studium porównawczego dotyczącego bajek La Fontaine'a z 1853 roku pt. De personis Platonicis. Essai sur

\footnotetext{
${ }^{9}$ Konstanty M. Górski, „Studia nad bajkami Krasickiego”, Przegląd Polski, no. 256 (1887), vol. $86(4,22): 37$.

${ }^{10}$ Ibidem, 61.

${ }^{11}$ Konstanty M. Górski, Pisma zebrane. Z badań nad literatura polska XVII i XVIII wieku, vol. I, ed. Stanisław Pigoń, intr. Kazimierz Morawski, (Warszawa: Gebethner i Wolff, 1913), 683-743.

${ }^{12}$ Przytacza przykłady decyzji translatorskich oddających istotę przekładów (łacina, niemiecki, francuski, włoski) lub dotyczących użycia konkretnych miar wierszowych i zastosowania oraz funkcjonalności konkretnych stóp wiersza. Uwzględnia również odmienność poszczególnych wydań i jej związek z motywacją tłumaczeń.
} 
les fables de La Fontaine. Nie tyle słynne trzy determinanty wykorzystywał Górski przy oglądzie twórczości Krasickiego, ile samą porównawczą metodę rozumienia osobowości poetyckiej, warunkowanej realiami kulturowymi, społecznymi i historycznymi.

Ważnym wątkiem badań Górskiego nad polskim Oświeceniem są studia monograficzne i biograficzne. Zarówno wcześniejsze prace o genologii bajki, jak i monografie bazujące na dokumentach, tworzą macierzysty kontekst dla późniejszych filologicznych rozpraw o poezji czasów stanisławowskich i dla nowelistycznej formy refleksji nad nią. W 1891 roku na łamach „Biblioteki Warszawskiej” Górski opublikował biograficzne studium Dziecinne i szkolne lata Karpińskiego (vol. II, 356-389), a kilka miesięcy później - utrzymaną w duchu poprzedniego tekstu Pierwsza młodość Karpińskiego (vol. IV, 33-65) ${ }^{13}$. W 1902 roku na łamach „Pamiętnika Literackiego” ponownie próbował tropić ślady biografii poetyckiej „śpiewaka Justyny” i wydał Karpińskiego we Wiedniu 1770-71 (1902, vol. I (1), 24-43), a dwa lata później - Karpińskiego w latach 1771-1780 („Pamiętnik Literacki” 1904, vol. III, 542-568) ${ }^{14}$. Fragmenty te złożyły się na monograficzne

${ }^{13}$ Warto dodać, że w tym samym roku o „śpiewaku Justyny” publikuje niezbyt obszerne studium biograficzne z elementami krytyki literackiej pt. Franciszek Karpiński Stanisław Marek Rzętkowski. Dokonuje tu oceny specyfiki warsztatu i poezji Karpińskiego oraz określa podobnie, jak to robi Górski, typ wrażliwości poetyckiej Karpińskiego. Stanisław Marek Rzętkowski, „Franciszek Karpiński”, Tygodnik Mód i Powieści, no. 44 (1891): 345-346.

${ }^{14}$ Przedruki tych tekstów oraz wcześniejszych studiów nad bajkami Krasickiego, studenckiej rozprawki Król Jan III w poezji polskiej XVII wieku oraz przetłumaczonej rozprawy doktorskiej Bajki... znajdują się w wydaniu pośmiertnym pism: Pisma zebrane, op. cit. Obszerne informacje dotyczące biografii i twórczości Górskiego zawierają dokumenty i papiery w Bibliotece Jagiellońskiej, rkps 7668 II - 7734 III, 7736 II. Z pośmiertnych ważniejszych opracowań warto wskazać: Adam Heydel, Jacek Malczewski. Człowiek i artysta (Kraków: Wydawnictwo Literacko-Naukowe, 1933), 100-106; Leon Kowalski, Pędzlem i piórem, intr. Jan Wiktor (Kraków [1934]), 143-162; Pia Górska, Paleta i pióro (Kraków: Wydawnictwo Literackie, 1956); Karol Estreicher, „Górski Konstanty Marian”, in Polski Stownik Biograficzny (Wrocław - Kraków, 1960), vol. VIII, 445-446; Andrzej Wanat, „Arystokrata nerwów", Życie Literackie, no. 39 (1968); Jadwiga Puciata-Pawłowska, Jacek Malczewski (Wrocław - Warszawa - Kraków: Ossolineum, 1968); Józef Dużyk, „Wstęp”, in „Listy Lucjana Rydla do Konstantego Mariana Górskiego", Pamiętnik Literacki, vol. 1 (1971): 171-173; Józef Mehoffer, Dziennik, ed. Jadwiga Puciata-Pawłowska (Kraków: Wyd. Literackie, 1975), 90, 378 (Mehoffer udzielał lekcji malarce - Pii - siostrze Konstantego, w Woli Pękoszewskiej); Jerzy Got [Jan Błoński], „Koniec plotki o trzech gwiazdkach”, Pamiętnik Teatralny, vol. XX (3-4) (1971): 351-354; Irena Maciejewska, „Konstanty M. Górski”, in Obraz literatury polskiej XIX i XX wieku. Literatura okresu Młodej Polski, ed. Kazimierz Wyka, Artur Hutnikiewicz, Mirosława Puchalska (Kraków: PWN, 1973), vol. III, 439-454. W dzienniku matki Górskiego, Marii z Łubieńskich Górskiej, na temat jej syna - nazywanego przez matkę Kociem - jest wiele fragmentów poświęconych rezonansowi twórczości syna oraz passusy informujące o tekstach Górskiego powstałych na gruncie warszawskim i krakowskim. Vide Maria z Łubieńskich Górska, Gdybym mniej kochała. Dziennik z lat 1889-1895 (Warszawa: Twój Styl, 1996); eadem, Gdybym mniej kochała. Dziennik z lat 1896-1906 (Warszawa: Twój Styl, 1997). Matka pisze na przykład 22 stycznia 1891 roku o transkrypcjach z Horacego w „Bibliotece Warszawskiej”, recenzjach teatralnych syna w Krakowie, listach Modrzejewskiej do 
studium komparatystyczne o autorze pieśni nabożnych, ocenione przez Stanisława Pigonia bardzo wysoko jako zamysł nowatorski ${ }^{15}$. Górski był też edytorem korespondencji śpiewaka Justyny.

Biograf zwraca uwagę na wielką popularność i poczytność Karpińskiego, potwierdzoną licznymi zestawieniami bibliograficznymi i artykułami w czasopismach z lat 20.-40. XIX wieku ${ }^{16}$. Przeszukując dziewiętnastowieczną krytykę literacką i stan badań, zauważa także, że tacy krytycy i historycy, jak chociażby Julian Bartoszewicz i Walery Przyborowski, nie darzyli sympatią Karpińskiego ${ }^{17}$. Górski zapewne celowo uwydatnia te nazwiska i wyraża jednocześnie żal wynikający z braku aprobaty dla spuścizny autora Pieśni nabożnych. Pisarze ci odegrali bowiem istotną rolę $\mathrm{w}$ przybliżaniu osiemnastowiecznych niuansów i meandrów historii. Powieści historyczne dla młodzieży, publicystykę zaangażowaną społecznie oraz historiografię obaj poświęcali zjawiskom znaczącym dla polskiego ducha narodowego, dla osiemnastowiecznych procesów dziejowych, dla osiemnastowiecznej codzienności.

Górski pokazuje charakter pisarstwa Karpińskiego na tle myśli etycznej i estetycznej Johanna Wolfganga Goethego i Karla Phillipa Moritza, a intymistykę polskiego poety zestawia z pamiętnikami Rousseau. Karpiński okazuje się w związku z tym

pierwszym u nas pisarzem, który nie tylko szczegóły ze swego życia, ale i obraz rozwoju swojej duszy daje, wspomina nie tylko o tym, co widział, ale i o tym, co się w nim samym działo. Rękopis pamiętników nosi wprawdzie tytuł „Historia mego wieku i ludzi, z którymi żyłem”, ale obok ciekawych przyczynków do dziejów epoki, zawierają one przede wszystkim dużo rozrzuconych, jakby bezwiednych rysów, objaśniających naturę piszącego. Mało tam wiadomości o pisarzu, ale dużo o wewnętrznym człowieku. [...] Głucha poezja kraju pozostała może nie bez wpływu; religijne życie tak rozbudzone w domu i w okolicy musiało ożywiać wyobraźnią i podsycać dalekie, nieokreślone pragnienia ${ }^{18}$.

Rozważając biografię Karpińskiego, Górski kładzie duży nacisk na ocenę jego nauki pobieranej u jezuitów w Stanisławowie. Przywołuje przykłady niesubordynacji młodzieńca, określa wpływ doświadczeń religijnych na kształtowanie wyobrażeń religijnych przyszłego autora kolędy Bóg się rodzi ${ }^{19}$. Daje wykład

Kocia o deklamacji jego wiersza (Maria z Łubieńskich Górska, Gdybym mniej kochała. Dziennik $z$ lat 1889-1895, 153-155). Vide Dawid Maria Osiński, „Mikrowymiar historii rodzinnej, czyli o wspomnieniowym zapisie Marii z Łubieńskich Górskiej na podstawie dziennika z lat 1889-1906 «Gdybym mniej kochała»", Prace Polonistyczne, vol. II (2006), LXI: 225-239.

${ }^{15}$ Stanisław Pigoń, „«Pisma literackie» Konstantego Górskiego”, Pamiętnik Literacki, vol. XII (1913): 482-483.

${ }^{16}$ Konstanty M. Górski, „Dziecinne i szkolne lata Karpińskiego”, Biblioteka Warszawska, vol. 2 (1891): 356

${ }^{17}$ Ibidem, 357.

${ }^{18}$ Ibidem, 374.

${ }^{19}$ Ibidem, 367-389. 
na temat szkolnictwa jezuickiego w Stanisławowie. Określa poetyckie próby czternastolatka jako przykład poszukiwania formy artystycznego wyrażenia poza magisterium łacińskiej retoryki (znanej choćby z gramatyki Alvareza) i przeciw normatywnym poetykom, wobec których uczeń gimnazjum stawał bezradny. Na podstawie pamiętników Karpińskiego odtwarza Górski dzieje jego edukacji i terminowania w szkole klasycyzmu, a także historię miłości ${ }^{20}$. Rekonstruuje drobiazgowo etapy miłości śpiewaka Justyny do Marianny Borselówny, pani Tamburini i pani de Warens. Wykorzystuje tę rekonstrukcję, aby zderzyć profil wychowania jezuickiego, nakazującego powściągliwość, z wyborami życiowymi poety. Dlatego Górski napisze m.in. w charakterze oceniającego podsumowania: „Zakochał się więc znowu z podziwu, z uznania cnót i zalet, i znowu uszlachetniał się we własnym mniemaniu, kochając zamężną kobietę. Nie lada kazuistą był ten jezuicki wychowanek!"21. Określa znaczenie życia artystycznego, literackiego, wydawniczego i towarzyskiego Lwowa oraz Lublina w biografii Karpińskiego.

Główny namysł monografista skupia na półtorarocznym pobycie Karpińskiego w Wiedniu, kiedy to poeta jako kapitan wyprawy wyruszył z przyjaciółmi znającymi język niemiecki przez Kraków do Wiednia. Pobyt w Wiedniu, który był wówczas pod silnym wpływem Francji i Prus (czyli cywilizacji zachodniej), to - jak zauważa Górski - ,jedyne wyjrzenie za granicę"22. Dlatego ten epizod biograficzny okazał się ważny dla całej późniejszej biografii i ścieżki artystycznej poety. Górski drobiazgowo relacjonuje rozpoznawanie się Karpińskiego w wiedeńskich realiach, jego trudności przy ocenianiu specyfiki tamtejszej kultury.

Studium biograficzne kończy omówieniem szczególnej religijności poety i jej znaczenia w rozumieniu poezji. Górskiemu bliski jest typ duchowości i uczuciowości Karpińskiego, zbliżony do franciszkańskiego dzięki zgodzie na skomplikowanie świata i pytaniom o miejsce wiary poza murami Kościoła jako instytucji. Ten rodzaj duchowości wiąże się z wiarą wynikającą z pierwotnych doświadczeń religijnych, których nie sposób zaklasyfikować i odnieść do konkretnej tradycji religijnej. Wiara ta wynika też z przynależności i budowania wspólnoty wśród ludzi wyznających podobne ideały i doświadczenia życiowe, których potwierdzeniem mogą być słowa Pieśni porannych i Pieśni wieczornych. Jest to wiara żywa, wyznająca piękno świata i Boga jako Stwórcę wszechnatury. Duchowość taką określa kodeks prostych prawd życiowych, potwierdzanych doświadczeniem człowieka w jego codziennym uwikłaniu. Górski upatruje w tym bliską panteizmowi istotę religijności Karpińskiego. Jeśli zważyć na wymowę kolędy Bóg się rodzi, pełną oksymoronów określających sytuację ontologiczną, związaną

${ }^{20}$ Konstanty M. Górski, „Pierwsza młodość Karpińskiego”, Biblioteka Warszawska, vol. 4 (1891): 33-65.

${ }^{21}$ Ibidem, 64.

${ }^{22}$ Konstanty M. Górski, „Karpiński w Wiedniu 1770-1771”, Pamiętnik Literacki, vol. I (1) (1902): 28-29, 43. 
z niezwykłością tej religijnej pierwotnej sceny, to trzeba przyznać, że dla neoklasycyzującego i parnasizującego (a więc zdystansowanego wobec życia i ujmującego je poza religijnym kodem) poety, jakim był sam Górski, rozsadzanie przez Karpińskiego obiegowych ujęć tej sceny, godziło w normatywność ewangelii biblijnych i apokryfów. Górski na koniec podkreśla: „Jak długo Karpiński jest religijnym człowiekiem i poetą, widzi wyłącznie w religii stronę jej, nie powiem, uczuciową, ale sentymentalną. Żyje resztami egzaltacji lat dziecinnych i wyczekuje słodyczy wewnętrznych poruszeń, czuje, poznaje Boga we własnym roztkliwieniu sercowym"23.

Uderzające są rzeczowość i konkretność pracy Górskiego nad bajkami Krasickiego oraz kompleksowość ujęcia biografii i dzieła Karpińskiego. Pokazują one z jednej strony osobność fascynacji krytyka liryką Oświecenia (wraz z oświeceniową wersją klasycyzmu i sentymentalizmu) na tle pewnej nieuwagi modernistów wobec tej poezji; z drugiej - przekonanie badacza o konieczności powrotu do tego dziedzictwa, aby rozpoznać jego istotę i specyfikę.

Powrót ten miał podstawowy cel. Było nim postawienie pytania o to, dlaczego w poezji oświeceniowej nie ma ducha tyrtejskiego, dlaczego w tekstach omija się fundamentalny problem stojący przed ówczesnymi: wybór między walką o polskość i o tożsamość narodową a ugodowością i lojalizmem, a także o kryteria identyfikacji postaw patriotycznych. Dlatego zapewne Górski zdecydował się na napisanie miniatury prozatorskiej, która byłaby głosem w tej sprawie. Jest on bowiem autorem noweli, dziś zapomnianej, a stanowiącej jedną z najciekawszych propozycji artystycznych i problemowych z galicyjskiego obszaru kulturowego przełomu XIX i XX wieku.

\section{Biblioman}

Tematem noweli Biblioman. Nowela. Z konkursu literackiego „Czasu”24, nagrodzonej trzecią lokatą w konkursie czasopisma w 1895 roku, jest los starszego człowieka, ekscentryka Sztremera (tytułowego bibliomana), który jeździ po kraju, żeby znaleźć pewną książkę. Bohater po dwunastu latach emigracji paryskiej wraca do kraju i osiada w Galicji. Daje lekcje matematyki i wykłada historię literatury, jest dozorcą na pensji dla panien, aż wreszcie zostaje bibliotekarzem w prywatnych domach. Dzięki otrzymaniu od brata pieniędzy z majątku po ojcu zamieszkuje we Lwowie, gdzie oddaje się pasji czytelniczej i bibliofilskiej. Każdy wolny czas poświęca na lektury w bibliotekach, dokonuje zapisków i wyciągów z białych kruków. W dyskusji z młodszym od siebie Gościszewskim

${ }^{23}$ Konstanty M. Górski, „Karpiński w latach 1771-1780”, Pamiętnik Literacki, vol. III (4) (1904): 567.

${ }^{24}$ Konstanty M. Górski, Biblioman. Nowela. Z konkursu literackiego „Czasu”, Kraków 1896. Dalej jako B i numer strony cytowanej. 
ujawnia powody zainteresowania poetami czasów stanisławowskich. Widać, że są to powody wynikające $\mathrm{z}$ pobudek patriotycznych, $\mathrm{z}$ niezgody na sprzyjanie protektorom i władzy albo na brak działania i milczenie w sprawach narodowych. Sztremer mówi bowiem o lojalizmie Karpińskiego, który pisał pochwalne wiersze dla Repnina (Do Księcia Mikołaja Repnina Jenerała Gubernator Litwy); wspomina wiersze poetów na cześć carycy Katarzyny, autoparodię Krasickiego („Święta miłości kochanej Ojczyzny” - „Wdzięczna miłości kochanej szklenice!”). Przywołuje wiersze i poematy cierpiącego na melancholię poety, który „Zwariował” - Franciszka Dionizego Kniaźnina. Mówi również o scenie patrzenia w kompas zawartej w Sofiówce Stanisława Trembeckiego czy „siedzeniu jak mruk w Janowie" przez Adama Naruszewicza podczas konfederacji targowickiej.

W rozmowie z Gościszewskim Sztremer wywołuje z pamięci historię swojej pracy bibliotekarza w pałacu w Józefpolu. Pewnej nocy, porządkując przy łojowej świecy skład książek, pism i manuskryptów, znalazł broszurkę w okładce marmurkowej „alla rustica” (B 22), której tytułu jednak nie pamięta. Wie tylko, że było to coś w stylu Zabawek wierszem i że na karcie tytułowej była wybita data i miejsce: „Sandomierz 1794” (B 22). Na odwrocie karty był napis: „Ten ostatni, zostały mi egzemplarz wierszów syna mego, poległego pod Racławicami, składam do stóp Jaśnie Wielmożnego Pana Wojewody w dowód wielkich i niezasłużonych łask Jego” (B 23), a w dalszej kolejności jeszcze nota: „Inne egzemplarze tej książki i cała drukarnia przez wojska Imperatorowej spalone były" (B 23). W tomiku, napisanym „zmysłowym dyskursem” najprawdopodobniej przez ucznia Korpusu Kadetów (B 24) ${ }^{25}$, znajdowały się: oda na ogłoszenie Konstytucji 3 maja, czterowiersz na transparent w dzień 3 maja, opisowy poemat o tamtych dniach w Warszawie, oda do zhańbionej ojczyzny, satyra na zdrajców, wiersz dla Tadeusza Kościuszki oraz wiersz pożegnalny dla matki.

Biblioman zagłębił się w lekturze. Intensywność czytania spowodowała chaos myślowy, toteż niewiele zapamiętał z tych wierszy, przypominał sobie jednak ich tytuły, łącznie z najważniejszym - Pieśnią do odrodzonej Ojczyzny. Zostało w nim silne wrażenie wyniesione z lektury i przekonanie o wadze tej patriotycznej poezji. Podstawowym wnioskiem, jaki płynął dla Sztremera z tego znaleziska, był ten, że Bóg ustrzegł nas jako naród od klęski i hańby milczenia. Dlatego pragnieniem bohatera stało się wydobycie nieznanego poety z ukrycia, przywrócenie go

${ }^{25}$ Warto dodać, że to, co pisze Górski w beletrystycznym tekście, wynika zapewne z lektury studiów Waleriana Kalinki. Te diagnozy naukowe wykorzystał również wnikliwie Kazimierz Bartoszewicz w jubileuszowej książeczce pt. Konstytucja 3 Maja. Kronika dni kwietniowych i majowych w Warszawie w roku 1791 (Warszawa: Jezierski, 1906). Bartoszewicz wydał ją jako wyraz powrotu do wspomnień zakazanych, jak czytamy w przedmowie (Kazimierz Bartoszewicz, Konstytucja 3 Maja. Kronika dni kwietniowych $i$ majowych $w$ Warszawie $w$ roku 1791, Warszawa: Epoka, 1989, 7), zintensyfikowanych po doświadczeniu rewolucji 1905 roku, przynoszącej ,żywy prąd wolności, który wstrząsnął posadami państwa rosyjskiego". 
światu i wydanie w „milionach egzemplarzy” (B 26). W błogości, wynikającej $\mathrm{z}$ wiary w rolę poezji walczącej, Sztremer zasnął. Kiedy obudził się rano, chciał dotknąć tomiku, jednak znalazł tylko spopielony papier. Był więc przekonany, że broszurka musiała spłonąć na stole.

Bohater nie jest pewien, czy tomik faktycznie istniał i czy proces lektury nie był sennym majakiem, ponieważ nie może tego sprawdzić i nie ufa swojemu przeżyciu. Spalone kartki nie dadzą się odtworzyć i nie ma dowodu, że naprawdę przeczytał wiersze patriotyczne z czasów insurekcji kościuszkowskiej. Dlatego treścią jego życia od tej pory staje się obsesyjne wręcz poszukiwanie w bibliotekach zachowanego egzemplarza książki. Znalezienie go pozwoliłoby odkłamać utartą kliszę myślową, jakoby epoka stanisławowska nie zostawiła po sobie patriotycznej poezji, pokazującej konieczność obrony wartości narodowych i duchowych, a tym samym przeciwstawiającej się poezji łzawej, salonowej, „balonowej”, sentymentalnej.

Sztremer wyrusza na dworzec kolejowy. Po jego wyjeździe w ciągu następnych miesięcy młodszy biblioman - Gościszewski - prowadzi porządkowanie józefpolskiego księgozbioru. W końcu otrzymuje informację o śmierci Sztremera - „słynnego archeologa” i „,znakomitego historyka literatury” - jak głosi gazeta z Przemyśla (B 30). Postanawia wtedy zatelegrafować do księcia (pryncypała) i prosić o dymisję. Po sfinalizowaniu wszelkich spraw biurokratycznych, pożegnaniu proboszcza i sługi Mikołaja, wyjeżdża furmanką na dworzec, żeby w świecie kontynuować dzieło poszukiwania rozpoczęte przez Sztremera i znaleźć ów tomik, o którym tamten mu opowiadał.

Pomysł Górskiego jest jednym z możliwych ujęć problemowych kształtu poezji późnego Oświecenia. Widoczne jest w nim dziewiętnastowieczne rozumienie powinności narodowych. Autorowi bliskie wydają się różnorodne techniki korzystania $z$ aluzji, sugestii czy nawet specyficznie widzianej mowy ezopowej, obecne w poezji pozytywistycznej i modernistycznej. W noweli niczego się kategorycznie nie stwierdza, a jedynie domniemywa. Wprowadzenie konwencji snu i atmosfery nocnej lektury tomiku wierszy powoduje, że niczego nie wiadomo na pewno. Jeśli zwróci się uwagę na liczne kryptopatriotyczne teksty, lirykę maski i mowę ezopową wierszy drugiej połowy XIX wieku, to owa aluzyjność i omowność nabiera znaczenia ${ }^{26}$.

Przez wątek szukania tomiku anonimowego autora poezji tyrtejskiej z lat 90. XVIII wieku Górski wyraża ideę potwierdzenia specyficznego głosu poezji tamtych lat. Znalezienie książki (w fabule noweli) byłoby szansą na pokazanie

${ }^{26}$ Oczywiście cała dziewiętnastowieczna formacja kulturowa (nawet postawa polskich pozytywistów) ujawnia, że walka o niezależność narodową i tożsamość czasami (dla dobra sprawy) wiąże się z koniecznością ustępstw czy ugodowości, w celu umożliwienia funkcjonowania w systemie szeroko pojętej kultury. Vide Marian Płachecki, Wojny domowe. Szkice z antropologii stowa publicznego w dobie zaborów (1800-1880) (Warszawa: IFiS PAN, 2009), zwł. rozdz. 15 stycznia 1872, 311-380. 
profilu poezji walczącej i poetyckich obrazów bohaterów, którzy nie zaprzedali się zdrajcom. Umożliwiłoby również zwrócenie uwagi na nowe widzenie patriotyzmu i odpowiedzialności, a także odpowiedź na pytanie o znaczenie wierności i hartowania charakteru w pieśni na polu bitwy, w działaniu. Dałoby wreszcie wzmocnienie znaczenia przesilenia późnoosiemnastowiecznego na ziemiach polskich, zobrazowanego w geście poety, który utrwalił te chwile w poezji.

Świadomość tego przesilenia, wynikającego z konsekwencji Maciejowic, Racławic, z dyskusji nad koniecznością Insurekcji, a potem z III rozbioru, wpisuje myślenie Górskiego jako nowelisty w kontekst późniejszych literackich głosów Tadeusza Micińskiego, Władysława Stanisława Reymonta, Stefana Żeromskiego, Wacława Berenta i Kazimierza Przerwy-Tetmajera (jako autora powieści z czasów napoleońskich, czyli trylogii Koniec epopei). Myślenie to spotyka się z wymową tekstów okolicznościowych lat 90 . XIX wieku, powstałych tuż przed publikacją noweli, zogniskowanych wokół stulecia rozbiorów ${ }^{27}$.

Przez wyeksponowanie bezkompromisowości i zawziętości bibliomana, ukierunkowanego w swoich działaniach na odnalezienie tomiku poetyckiego, autor noweli pokazuje również znaczenie ideałów w życiu człowieka. I choć daleko jeszcze do zmiany optyki myślenia młodopolan uwarunkowanej doświadczeniem rewolucji 1905 roku i Wielkiej Wojny, to widać, że Górski próbuje odpowiedzieć na pytanie o obecność idei narodowowyzwoleńczych w literaturze drugiej połowy i końca wieku XVIII, a tym samym zapytać o rolę i znaczenie odpowiedzialności za los narodu w literaturze o wiek późniejszej - końca XIX wieku.

\section{Po co Oświecenie}

Czy literacka wizja oświeceniowej poezji patriotycznej z noweli Biblioman w intencji Górskiego miała być dopełnieniem idei oświeconych? A może miała wyznaczyć punkt, od którego zaczyna się pytanie o granice odpowiedzialności za czyn i słowo? Trudno jednoznacznie to ocenić, ale jedno jest pewne. Górski w nowelistycznym przekazie dokonuje niejako rehabilitacji poezji późnego Oświecenia, ale też restytucji tekstów patriotycznych z przełomu XVIII i XIX wieku, które świadczyły o znaczeniu poezji zaangażowanej, choć siła ich oddźwięku była niedostateczna. Sugeruje (zachowując konwencję niepewności), że poezja $\mathrm{z}$ ducha tyrtejska, kształtująca się w obliczu politycznej niewoli, mogła mieć swoją reprezentację i być głosem w sprawie.

${ }^{27}$ One to wyznaczały profil ówczesnego zaangażowania i czy to dzięki patriotycznej bibule kolportowanej pod presją więzienia czy szubienicy, czy pismom oficjalnym, czy żywym obrazom - przypominały trudne i ważne momenty sprzed stu lat, zarówno te zwycięskie i chlubne (jak Konstytucja 3 maja czy Racławice), jak i te związane z upadkiem, hańbą i ostatecznym rozkładem Rzeczpospolitej. 
Zawarty w utworze Górskiego pomysł poszukiwania zaginionego tomiku (metonimii poezji) uruchamia lekturę noweli bliską alegorezie. Dochodzenie, czy faktycznie istniał tomik wierszy świadczący o zaangażowaniu jego autora w ówczesną sytuację historyczną, określa konieczność znalezienia dla poezji tamtego czasu właściwego miejsca i statusu. Sądzę, że w swój zamysł literacki Górski wpisał ujęcie nazywane dziś w badaniach alegorezą. Nie jest ono alegorią, ponieważ nie ma tu jednoznacznego i obrazowego przedstawienia idei i pojęććc ani figury określającej pewien jednoznacznie sugerowany modelowy obraz, abstrakcyjne pojęcie czy ideę ${ }^{29}$. Pomysł Górskiego dotyczy obszaru szczególnego, bo jedynie sugerowanego i postulowanego. Ujęcie bliskie alegorezie wyzwalałoby tu więc mechanizm niepewnej (niedokładnej) komunikacji związany z pytaniami o intencje nadawcy oraz możliwości zrozumienia po stronie odbiorcy. Nie chodzi mi tu jednak o rozumienie alegorezy, które kazałoby szukać swoistych figur myśli oraz zależności między alegorią a wypowiedzią literacką (na poziomie języka). Sądzę, że literacki zamysł Górskiego można oddać, posługując się cytatem z pracy Janiny Abramowskiej, która dowodzi, że

\begin{abstract}
Budowanie tekstu alegorycznego, z powodu różnych sygnałów odsyłającego do ściśle wymaganego drugiego planu znaczeń, ma więc odpowiednik w alegorycznym stylu lektury. Hermeneutyczne jądro zjawiska ujawnia się w pełni w tej właśnie praktyce interpretacyjnej, którą Morton W. Bloomfield również nazywa alegorią, a którą wolę dla porządku określać mianem alegorezy. Mieszcząca w sobie obie strony, sposób pisania i sposób czytania, praktyka alegoryczna daleko wykracza poza retorykę i trudno ją zmieścić w kategoriach opisowych ${ }^{30}$.
\end{abstract}

Proces dochodzenia do pytań o wymiary polskiego Oświecenia i jego poezji (o różnorodność tematyczną i estetyczną wierszy Krasickiego czy Karpińskiego, o poezję religijną, poezję zaangażowaną) określa specyfikę myślenia Górskiego. Kiedy spojrzy się bowiem na naukowy, edytorski i literacki aspekt namysłu Górskiego nad polskim Oświeceniem i polskim wiekiem XVIII, to widać, że ten przenikliwy krytyk, poeta i badacz u progu XX wieku rozumiał doskonale

${ }^{28}$ Vide Nortrop Frye, Anatomy of Critisism (Princeton: Princeton University Press, 1957); Michel Foucault, Les mots et les choses: Une archéologie des sciences humaines, Paris: Gallimard, 1966; Aleksandra Okopień-Sławińska, [hasło] 'alegoria' , in Słownik terminów literackich, ed. J. Sławiński et al, Wrocław 1988, wyd. II poszerzone i poprawione, 22-23; Paul de Man, Alegorie czytania. Język figuralny u Rousseau, Nietzschego, Rilkego i Prousta, trans. Artur Przybysławski (Kraków: Universitas, 2004), zwł. rozdz. Alegoria czytania (,Wyznanie wiary”), 264-292; Michał Rusinek, Między retoryka a retorycznościa (Kraków: Universitas, 2003), zwł. rozdz. Figuratywność, 139-210.

${ }^{29}$ Vide Kleines literarisches Lexikon. Dritte, völlig erneuerte Ausgabe. Erster Band, bearbeitet von Albin Euduard Beau i inni, herausgegeben von Wolfgang Kayser (Francke Verlag Bern und München, 1961), Band 15; hasło 'allégorie', in Henri Morier, Dictionnaire de poétique et retorique et de rhétorique (Paris: Press Universitaires de France, 1975), 65-68 (zwłaszcza pola (koła) zależności znaczeniowej określające wynikowość konkretu i abstraktu).

${ }^{30}$ Janina Abramowska, ,Rehabilitacja alegorii”, in Alegoria, ed. Janina Abramowska (Gdańsk: słowo/obraz terytoria, 2003), 6 . 
przyczyny złożoności i wielopostaciowości polskiego Oświecenia. Tę niejednorodność potwierdzili późniejsi badacze ${ }^{31}$. W myśleniu Górskiego Oświecenie stanisławowskie traktowane jako formacja kulturowa projektuje się jako siedlisko nie służalczości i ugodowości, ale przestrogi i ocalenia patriotyzmu. Zaginiony tomik z noweli jest upostaciowieniem idei buntu i niezgody. Górski tą literacką miniaturą mówi o samej konieczności walki, buntu i niezgody, która określa ramy patriotycznego kodeksu. W ten sposób rzuca nowe światło na poezję stanisławowską i postanisławowską.

\section{Kontekst. Ostap Ortwin}

Po pięciu latach od zakończenia I wojny światowej w odczycie (wygłoszonym jako jeden z cyklu wykładów na Uniwersytecie Ludowym im. A. Mickiewicza we Lwowie) Ostap Ortwin dokonał rekonesansu współczesnej liryki polskiej. Dostrzegł wówczas zarówno morfologiczne, genologiczne, jak i tematyczno-problemowe (,anatomiczne”) jej zmiany, a także nowe funkcje poezji po odzyskaniu niepodległości. Zwracał również uwagę na tymczasowość przeobrażeń liryki. Podkreślał, że nie jest to pierwszy taki moment w dziejach literatury polskiej, kiedy „wstrząsające fakty historyczne o olbrzymiej doniosłości dla życia narodowego, które zaważyć muszą na całej jego przyszłości, nie znajdują bezpośredniego oddźwięku w liryce współczesnej” ${ }^{32}$. Lokował lirykę po I wojnie w obrębie paradygmatu młodopolskiego.

Próbował wskazać, jakie są wyzwania, przed którymi stają nowi poeci wobec nowego porządku świata. Znamienne, że przywoływał tu Ortwin również ówczesną wiedzę o liryce polskiego Oświecenia, łącznie z przekonaniem o braku w tej poezji patriotycznego ducha, braku odpowiedzialności za formy ówczesnych

${ }^{31}$ Mam tu na myśli badania Wacława Borowego nad specyfiką poezji XVIII wieku (od czasów saskich i Elżbiety Drużbackiej, przez poezję księdza Baki, pieśni konfederatów, poezję stanisławowską aż do poezję schyłku wieku, Staszica, Woronicza, Niemcewicza) oraz późniejsze badania Teresy Kostkiewiczowej, Jerzego Snopka, Tomasza Chachulskiego, Zofii Rejman, Barbary Czwórnóg-Jadczak, a zwłaszcza Marcina Cieńskiego i Piotra Żbikowskiego. Vide Wacław Borowy, O poezji polskiej w wieku XVIII (Warszawa: PIW, 1978); Teresa Kostkiewiczowa, Oświecenie. Próg naszej wspótczesności (Warszawa: Semper, 1994); eadem, Studia o Krasickim (Warszawa: IBL PAN, 1997), zwł. rozdz. Krasicki a oświecenie, 135-162; Tomasz Chachulski, Franciszek Karpiński (Warszawa: IBL PAN, 1998); Zofia Rejman, Świadomość literacka polskiego Oświecenia. Wybrane problemy (Warszawa: Wydział Polonistyki UW, 2005), zwł. rozdz. Zmierzch klasycyzmu?, 10-43; Barbara Czwórnóg-Jadczak, Klasycy i romantycy, zwł. rozdz. „Wiersz do Legionów Polskich” Cypriana Godebskiego. Dokumentaryzm i peryfrastyczność (Lublin: UMCS, 2012), 21-29; Marcin Cieński, Literatura polskiego Oświecenia wobec tradycji i Europy. Studia (Kraków: Universitas, 2013); Piotr Żbikowski, „...bolem śmiertelnym ściśnione mam serce...”. Rozpacz oświeconych. U źródet przełomu w poezji polskiej w latach 1793-1805 (Wrocław: Wyd. FNP, 1998).

32 Ostap Ortwin, „Współczesna liryka polska”, in idem, Żywe fikcje. Studia o prozie, poezji $i$ krytyce, ed. Jadwiga Czachowska, intr. Michał Głowiński (Warszawa: PIW, 1970), 186. 
polityczno-historycznych przeobrażeń. Posługiwał się jednak używanymi wtedy powszechnie stereotypowymi sądami o liryce oświeceniowej. Ortwin określał tę lirykę jako niepatriotyczną, pozbawioną tyrtejskiego ducha formę zabawy słowem. Jego punkt widzenia wynikał więc z niewłaściwego rozumienia mowy ezopowej osiemnastowiecznych tekstów poetyckich kodujących fundamentalne diagnozy ówczesnej sytuacji politycznej. Ortwin nie brał pod uwagę utworów ściśle patriotycznych z czasów konfederacji barskiej (1768) i z czasów Sejmu Czteroletniego (1788-1792) czy zwłaszcza kryptopatriotycznych późnooświeceniowych dzieł świadczących o antynomiczności polskiego Oświecenia, o której później pisali Ryszard Przybylski i Marcin Cieński ${ }^{33}$. I choć Ortwin przywoływał nazwiska autorów Barda polskiego (1795, wyd. 1840), Adama Jerzego Czartoryskiego czy Jana Pawła Woronicza, to twierdził, że realizacje poetyckie tych poetów były łabędzim śpiewem dawnej klasycystycznej formy i słabo słyszalnym głosem ówczesnej poezji.

A przecież dzisiaj wiadomo, że poza dyskursem publicystycznym czy historiograficznym, mówiącym o patriotyzmie (czego przykładem są m.in.: Listy patriotyczne Józefa Wybickiego z 1776 roku wzywające rządzących do wzięcia odpowiedzialności za ojczyznę i Stanisława Staszica Przestrogi dla Polski z 1790 roku), potwierdzeniem obecności poezji zaangażowanej są w polskim Oświeceniu pieśni konfederatów barskich (ale te znane głównie w wersji śpiewanej bądź $\mathrm{z}$ rękopisów, na co zwraca uwagę Jerzy Snopek ${ }^{34}$ ), a także patriotyczne wiersze okresu przesilenia oświeceniowego: Wiosna (1793) czy Smutki (1793) Juliana Ursyna Niemcewicza, Smutki (1793) Hugona Kołłątaja, Treny na rozbiór Polski Józefa Morelowskiego czy wreszcie słowa Mazurka Dąbrowskiego (1797) Józefa Wybickiego ${ }^{35}$.

\footnotetext{
${ }^{33}$ Ryszard Przybylski, Klasycyzm czyli Prawdziwy koniec Królestwa Polskiego (Warszawa: PIW, 1983), zwł. 139-140 (dotyczące Sofiówki Trembeckiego), a także rozdziały poświęcone Woroniczowi i Godebskiemu czy Rozmowom zmarlych Krasickiego; Marcin Cieński, op. cit. Ryszard Przybylski zwraca na przykład uwagę na odpowiedź Solona z Rozmów zmarlych Krasickiego (literackich dysput toczonych na Polach Elizejskich). Vide R. Przybylski, Klasycyzm czyli Prawdziwy koniec..., 134.

${ }^{34}$ Jerzy Snopek, Oświecenie. Szkic do portretu epoki (Warszawa: PWN, 1999), 125-126.

${ }^{35} \mathrm{O}$ znaczeniu poezji doby przesilenia oświeceniowego traktują studia Piotra Żbikowskiego. Piotr Żbikowski, op. cit. Piotr Żbikowski, podobnie jak Teresa Kostkiewiczowa, pokazuje produktywność literacką czasu przesilenia oświeceniowego trwającego od lat 90. XVIII wieku do lat 30. XIX wieku. Piotr Żbikowski, „Poezja oświeceniowo-romantycznego przełomu (1792-1830). Próba periodyzacji”, in Na przełomie Oświecenia i Romantyzmu. O sytuacji w literaturze polskiej lat 1793-1830, ed. Piotr Żbikowski (Rzeszów: Wyd. WSP, 1999), 23-46; Teresa Kostkiewiczowa, „Notatki do syntezy historii literatury polskiej po rozbiorach”, in Na przełomie Oświecenia i Romantyzmu, 11-22. Piotr Żbikowski uważa bowiem, że ujęcia problemów niepodległościowych w poezji polistopadowej i w wielu utworach z lat 1792 - 1805 - 1807 są podobne. Badacz dowodzi, że ponad 300 utworów tamtego czasu ma fundamentalną dla okresu przejściowego (przesilenia), a nie tylko tradycji romantycznej, formę poematu, melodramy komediowej, hymnu, ody, psalmu, trenu, żalu, dumy, pieśni, elegii, modlitwy, listu poetyckiego, listu z wierszami, panegiryku, bajki, epigramatu,
} 
Ortwin pisał z przejęciem. Dyskurs krytyczny niewolny od retorycznych cech języka młodopolszczyzny, złożony z wielu upodrzędnionych członów wypowiedzeń, wybrzmiewał następująco:

W dobie utraty niepodległości na szczytach literatury, w poezji Trembeckich, Krasickich i Naruszewiczów, Karpińskich czy Kniaźninów, na próżno by szukać jakiegokolwiek dokumentarnego śladu odczucia przez nich tragicznej katastrofy państwowości polskiej. Na fakt ten elita ówczesnej literatury naszej zareagowała milczeniem. [...] Przypuszczać raczej trzeba, pomijając kwestię indywidulanych niedomogów w uzdolnieniach, że ani ówczesny styl poetycki, ani panująca w literaturze konwencja i pojęcia estetyczne, ani tradycjonalny zasób ówczesnych form poetyckiego wysłowienia nie dawał poetom odpowiednich środków wyrazu dla obiektywizacji patriotycznych stanów duszy za pomocą równoważników językowych w jednolicie zorganizowanej konstrukcji ideodźwiękowej. Stąd poszło, że nawet gdy ktoś z przedstawicieli ówczesnego pokolenia, oficjalnie niezaliczany zresztą do majstrów, systematycznie i z powołania kult poetycki uprawiający, jak autor Sybilii, czcigodny później biskup krakowski Jan Paweł Woronicz, ks. Adam Czartoryski w swym Bardzie polskim, usiłował na uboczu, w prywatnych niejako rękopisach, zrazu nie ogłaszanych nawet drukiem, uczuciom swym losami ojczyzny do głębi wstrząśniętym nieśmiały dać wyraz, nie umiał opierając się o zadawnione wzory i nawyknienia poezji tych nowych i nieznanych przedtem stanów duszy wcielić w formy równoważne o dostatecznej sile napięcia ${ }^{36}$.

Oczywiście krytyk mówił tu o czasach klasycyzmu stanisławowskiego, polskiej wersji rokoka i sentymentalizmu. Ale nie miał na uwadze tekstów znamionujących „prawdziwy koniec Królestwa Polskiego”, o których pisze Ryszard Przybylski w przywołanej monografii problemu czy Piotr Żbikowski. Jednak sugerowanie rzekomego braku poezji patriotycznej tego czasu ujawnia w myśleniu Ortwina oczekiwanie jej obecności, podobne do oczekiwania, które zawarł Górski w swojej noweli. Samo postawienie problemu patriotyzmu poezji polskiego Oświecenia wydawało się im obu kwestią prymarną, choć każdy z nich miał na myśli inny obraz tej poezji.

Ortwin nie brał pod uwagę różnorodnych i ważnych dla czasów porozbiorowych tekstów, które konstytuowały myślenie o tragicznym pokoleniu stanisławowskim. Ale skoro celem rozpoznań krytyka było pokazanie, co się działo w ówczesnej poezji (właśnie w poezji, a nie po prostu w tekstach wierszowanych, nazywanych powszechnie poezją przez wzgląd na formę zapisu), to może się to wydać zrozumiałe; poza jednym wyjątkiem, którym, jak sądzę, jest pominięcie

pamfletu, pastiszu (28). Dokonuje typologii ze względu na wątki tematyczne, postawy uczuciowe i stan ducha oraz sytuację egzystencjalną i wyodrębnia w tym czasie 19 typów estetyki tekstów (29-32). Inaczej ten problem widzi Marek Nalepa, który na przykładzie biografii twórczej Krasickiego dowodzi jego milczenia poetyckiego po III rozbiorze. Vide Marek Nalepa, „Milczenie poetów stanisławowskich”, in Myśl - stowo i milczenie. Wokót zagadnień świadomości literackiej i praktyki twórczej, ed. Piotr Żbikowski (Wrocław: Ossolineum, 1997), 41-81; idem, „Milczenie poety i mędrca - Ignacy Krasicki a trzeci rozbiór Polski”, in Od Oświecenia do romantyzmu. Prace ofiarowane Piotrowi Żbikowskiemu, ed. Gustaw Ostasz et Stanisław Uliasz (Rzeszów: Uniwersytet Rzeszowski, 1997), 85-105.

${ }^{36}$ Ostap Ortwin, op. cit., 186. 
zaangażowanej poezji konfederatów barskich. Choć przywołuje Ortwin Barda polskiego, to przecież jakby celowo pomija tyrtejskie i polityczne liryki z czasów konfederacji, zawiązanej przeciw rządom króla Stanisława Augusta Poniatowskiego - czyli formalnie przedstawiciela prawowitej władzy państwowej ${ }^{37}$. Można by upraszczająco powiedzieć: jakby czytał studia Górskiego o Oświeceniu, ale nie doczytał Bibliomana, który wątek patriotycznej poezji czasów późnego Oświecenia wydobywa i przez to przyznaje należytą wartość liryce tego czasu. Passus Ortwina z 1923 roku był jednak pewnego rodzaju podsumowaniem poezji oświeceniowej (chociaż nie oddawał istoty ważnego jej wymiaru, jakim był tyrtejsko-patriotyczny ton poezji lat 90 . XVIII wieku) i rekonesansem krytycznym współczesnej poezji. Umożliwiał on bowiem po doświadczeniach I wojny lepsze rozumienie jej statusu i wyborów tematycznych.

\section{KONSTANTY MARIA GÓRSKI'S RESEARCH ON THE ENLIGHTENMENT}

\section{Sum mary}

The present discussion sheds light on the works and worldview related to Polish Enlightenment of Konstanty Maria Górski (1862-1909), a writer, poet, historian and expert on Enlightenment in Polish literature. Although Górski was an individualist in the Young Poland movement, as a scientist and writer he was a representative of his time. The article shows the ways in which the microdimensions of Enlightenment in Górski's scientific biography may be understood. His line of thought reveals the aspects, borders and definitions of Polish Enlightenment by means of scientific interpretations of biographies of the writers of the period as well as by specifying the cultural, esthetical and ideological movement known as Enlightenment. The field of Górski's scientific exploration focuses on the $90 \mathrm{~s}$ of the $18^{\text {th }}$ century and helps to understand why the theme and fascination with Polish Enlightenment, especially with the 90 s of the $18^{\text {th }}$ century which was such a difficult time for Polish culture and national identity as it was connected with national partitions and hope for resurrection and liberation, becomes a cornerstone of Górski's scientific development as a researcher trying to resolve specific problems in Polish literature at that very time. The author discusses the manner in which many different problems connected with Polish Enlightenment are presented in Górski's biography and works. The purpose of the article is to present the specific mechanism which could be compared to allegoresis, used by Górski in his short story Bibliomaniac (Polish title: Biblioman).

${ }^{37}$ Znamienne okazuje się to, że w namyśle nad poezją oświeceniową (podobnie jak w myśleniu o kształcie poezji po I wojnie światowej) Ortwin nie uwzględnia kwestii związanych z istotą poezji narodowej i ujawnianiem jej zaangażowania patriotycznego, choć ich wagę uświadomiły już dużo wcześniej choćby wykłady Adama Mickiewicza w Collége de France, jak i różnorodne studia o charakterze syntez czy nawet wstępów edytorskich do wydań pod koniec XIX wieku (np. poezji Franciszka Karpińskiego Piotra Chmielowskiego). 